\title{
MUQARNAS: \\ Ungkapan Keagungan Nilai Islam dalam Karya Arsitektur
}

\author{
Yulia Eka Putrie \\ Jurusan Teknik Arsitektur Fakultas Sains dan Teknologi Universitas Islam Negeri Malang, \\ Jalan Gajayana No.50 Malang, Telp. 081233447407
}

Abstract

Muqarnas is the Arabic word for stalactite vault, a three-dimensional decoration element in Islamic architecture. Inspired by honey comb, this kind of architectural ornament has been developed to the highest form of aesthetics and complexity. Its uniqueness is laid on its geometrical composition, which is transformed from thousands of cells, tiers and intermediate elements. Inspite of its amazing geometrical composition, there are some values and meanings that consist in muqarnas. Infinitive design of muqarnas is mostly based on human's awareness of God's infinite highness and strength. Furthermore, it shows us that Allah's creation such as honey combs, that is often being underestimated by human, contain huge of knowledge and complicated calculations. These kind of awareness and wisdoms are yielded by artists and architects in the past, who had never detached science from Islam, as the way of life.

Key words: muqornas, islamic architecture, the art of decoration 


\section{Pendahuluan}

Seni dekorasi merupakan salah satu unsur pembentuk karakter yang terpenting dalam arsitektur Islam. Seni ini berkembang sampai pada tingkat kompleksitas dan keindahan yang sangat tinggi. Sebagian besar motif yang digunakan dalam seni dekorasi ini, terinspirasi dari unsur-unsur alam dan komposisi geometris. Bunga-bungaan dan sulur-sulur tanaman jalin-menjalin dalam perulangan-perulangan bentuk yang menghasilkan keindahan yang rumit namun tetap bersahaja.

Salah satu bentuk terindah dari seni dekorasi ini, adalah muqarnas. Muqarnas merupakan wujud dekorasi tiga dimensi pada interior kubah bangunan, yang terinspirasi oleh komposisi geometris sarang lebah. Kata muqarnas berasal dari bahasa Arab, yang berarti kubah stalaktit ${ }^{1}$. Tidak seperti seni dekorasi lain yang umumnya berwujud dua dimensi, muqarnas bertransformasi menjadi seni dekorasi yang meruang. Hal inilah yang menjadikan muqarnas menarik untuk dikaji secara mendalam, mulai dari segi estetika bentuk, fungsi, sampai pada tataran makna dan pelajaran yang dapat diperoleh dari keberadaannya.

Seperti telah kita ketahui, bahwa keagungan yang muncul dari berbagai karya arsitektur Islam, berasal dari kedalaman makna dan penerapan nilainilai Islam (Islamic values) yang melatarbelakangi kehadiran bentuk. Nilainilai inilah, yang sebenarnya merupakan penentu kualitas karya arsitektur dalam dunia Islam. Keindahan bentuk yang muncul setelahnya, merupakan manifestasi keindahan nilai-nilai dan cara pandang (world view) dalam Islam yang diwujudkan dalam hasil-hasil kebudayaan, diantaranya adalah karya arsitektur. Hal ini berlaku pula pada muqarnas. Keindahan yang ditampilkannya, merupakan manifestasi makna yang lebih dalam dari keagungan nilai-nilai Islam. Hal inilah yang akan diangkat dalam hasil kajian pustaka ini.

\section{Persebaran Muqarnas di Dunia Arsitektur Islam}

Dalam banyak karya arsitektur Islam di Spanyol, Afrika Utara dan Asia Tengah, muqarnas dipergunakan sebagai salah satu elemen dekoratif utama pada interior dan eksterior istana, masjid dan objek arsitektur lainnya. Bentuknya yang menggantung seperti sarang lebah, membuat muqarnas banyak diletakkan pada tempat-tempat yang tinggi pada bangunan. Desain muqarnas diterapkan pada kubah-kubah, relung pintu gerbang, jendela, kolom dan langit-langit ruang. Sebagian besar muqarnas terdapat di dalam ruang, dan sebagian kecil lainnya terdapat pada eksterior bangunan, seperti balkon minaret dan relung pintu gerbang. 


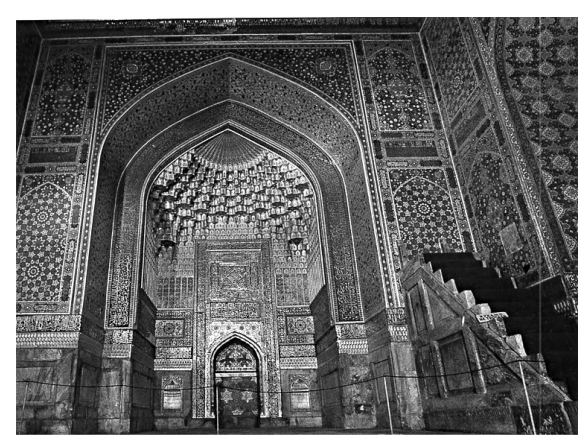

Gambar 1. Muqarnas pada relung mihrab masjid Tilla Kari di Samarqand, Uzbekistan. Sumber: M.Hattstein \& P. Delius, p. 443

Di Masjid I-Jami Isfahan, Iran, muqarnas ditemukan pada bagian-bagian tertua dari masjid dan bagian kiblat yang dibangun di abad ke-11. Muqarnas juga ditemukan pada bagian koridor (iwan) yang dibangun pada abad ke-12, dan pada bagian-bagian yang mengalami renovasi pada abad ke-15 dan 16 . Menurut perkiraan para ahli sejarah, muqarnas yang terdapat pada bagian tertua masjid ini didesain oleh seniman-seniman Saljuk. Seniman-seniman Saljuk inilah yang dikenal pada awalnya merancang dan mengembangkan desain muqarnas, lihat Gambar 2 dan 3. (www.muslimheritage.com).

Sementara itu, di Alhambra Palace Granada, Spanyol, muqarnas dijadikan elemen dekoratif pada sebagian besar elemen arsitektural dan struktural. Kolom-kolom, dinding, jendela-jendela, gerbang, koridor dan relung-relung atap dihiasi dengan komposisi geometris ini. Dua buah kubah muqarnas terindah berwarna keemasan, tergantung di relung atap dua ruang kediaman yang terpisah, yang dikenal dengan nama 'the Hall of the Two Sisters' dan 'the Hall of Abencerrajes' (Esposito, 1999: 22). Muqarnas pada kedua kubah ini memiliki lebih dari 5000 satuan sel berbagai ukuran yang membentuk komposisi tiga dimensional yang sangat indah, lihat Gambar 4 dan 5 (www.mrfs.net).

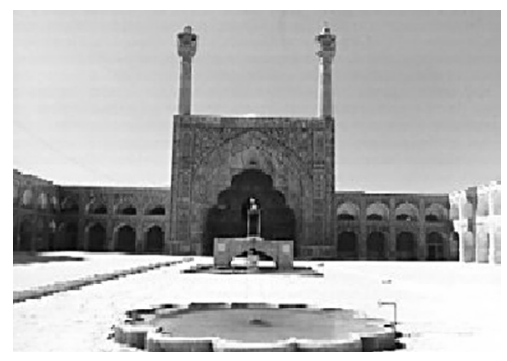

Gambar 2. Masjid I-Jami di Isfahan, Iran. Sumber:http://www.muslimheritage.com 


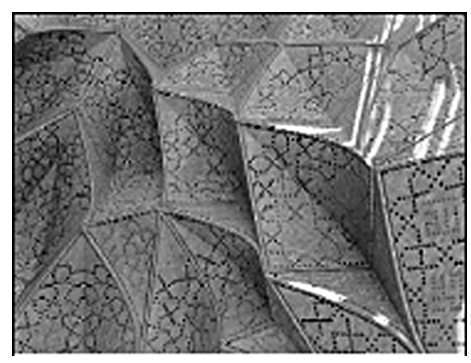

Gambar 3. Muqarnas pada iwan (koridor) Masjid I-Jami Isfahan, Iran, yang berbentuk setengah kubah. (Sumber:www.muslimheritage.com)
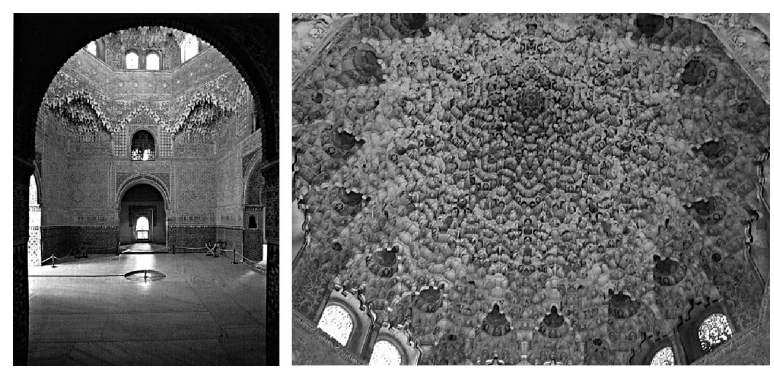

Gambar 4. Muqarnas pada 'the Hall of the Two Sisters', Alhambra Palace Granada, Spanyol. Sumber: M.Hattstein \& P. Delius, p.292 dan www.mrfs.net

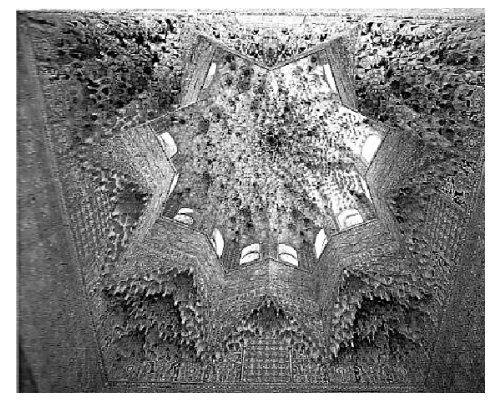

Gambar 5. Kubah Muqarnas pada 'the Hall of Abencerrajes', Alhambra Palace Granada, Spanyol. Sumber: M.Hattstein \& P. Delius, p.293

Salah satu contoh penerapan muqarnas pada elemen eksterior bangunan, ditemukan pada bangunan-bangunan makam dan masjid di Kairo, Mesir. Sebagian besar dibangun pada masa kekuasaan dinasti Ayyubid dan Mamluk (Hattstein, 2000: 190). Dalam kompleks bangunan makam Sultan Qaitbay di sebelah timur Kairo, muqarnas menghiasi balkon-balkon minaret, dikombinasikan dengan ornamen-ornamen geometris dan motif-motif floral, membentuk komposisi vertikal dengan tingkat estetika yang tinggi, lihat gambar 6 . 


\section{Desain Geometris Muqarnas}

Salah satu keistimewaan muqarnas yang telah disebutkan di atas, adalah elemen dekoratif ini merupakan elemen dekoratif yang meruang, ketika sebagian besar elemen dekoratif lainnya terbatas pada bidang dua dimensi. Dalam penerapannya, muqarnas dapat bertransformasi menjadi bentuk yang benarbenar tiga dimensional, seperti yang terdapat pada kubah-kubah dan relung pintu gerbang, dapat pula menjadi elemen dekoratif semi dua dimensional, seperti yang terdapat pada permukaan dinding dan jendela. Lihat Gambar 7.

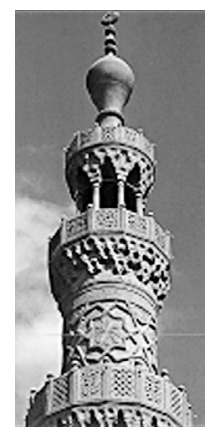

6

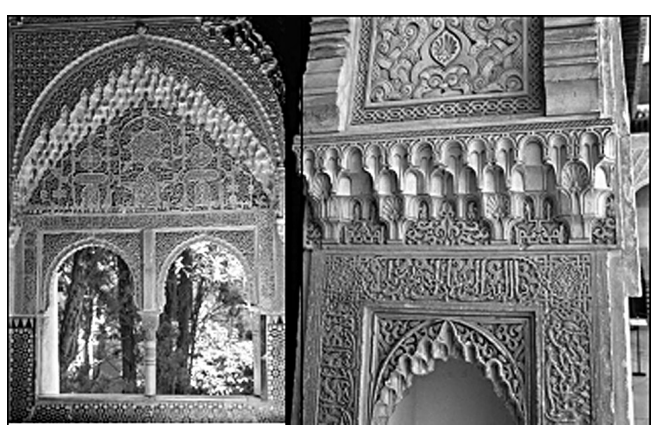

7

Gambar 6. Dekorasi muqarnas pada balkon minaret Makam Sultan Qaitbay, Kairo, Mesir. Sumber: M.Hattstein \& P. Delius, p.190.

Gambar 7. Muqarnas sebagai elemen dekoratif semi dua dimensional pada jendela dan kepala kolom. Sumber: www.collection1.libraries.psu.edu

Menurut ahli Matematika Timurid abad ke-15, Ghiyath al Din Mas'ud al Kashi, muqarnas adalah suatu unit tiga dimensional yang dapat diproyeksikan ke dalam suatu garis besar bidang dua dimensional. Dalam proyeksi dua dimensional, desain muqarnas terdiri dari dua elemen pembentuk dasar, yaitu sel dan elemen perantara. Terdapat enam bentuk sel dan elemen perantara yang paling sering digunakan, yaitu bujur sangkar, belah ketupat, jajaran genjang, kendi, biped (dua kaki) besar, dan biped (dua kaki) kecil (www2.iwr. uni-heidelberg.de). Dapat dilihat pada gambar 8 di bawah ini.

Bentuk bujur sangkar, belah ketupat dan kendi digunakan sebagai sel, sedangkan bentuk biped kecil dan biped besar digunakan sebagai elemen perantara. Sementara itu, bentuk jajaran genjang (rhombus) digunakan baik sebagai sel, maupun sebagai elemen perantara. Hasil komposisi bentuk-bentuk dasar ini dapat diproyeksikan menjadi bidang dua dimensi yang dapat dilihat pada gambar 9. 
Komposisi sel-sel dan elemen perantara ini memiliki fleksibilitas yang tinggi untuk diterapkan pada hampir semua permukaan dan relung. Ukuran modul sel dan elemen perantara berubah-ubah sesuai dengan volume ruang yang akan ditempati. Sel-sel dan elemen perantara kemudian disusun menurut pola recilinear atau grid-grid melingkar. Pola-pola ini kemudian disusun saling menopang satu sama lain. Dengan demikian, muqarnas merupakan penerapan dari sistem linier (dua dimensi) sekaligus sebagai pengaturan massa (tiga dimensi). Satu hal yang tidak kalah menarik dalam perkembangan desain muqarnas di dunia arsitektur Islam, adalah adanya jalinan benang merah yang tidak terputus, mulai dari periode Ilkhanid sampai ratusan tahun sesudahnya. Perkembangan desain muqarnas menjadi bentuk-bentuk bintang bersegi lima, enam atau tujuh, tetap tidak meninggalkan bentuk-bentuk dasar yang telah dibahas di atas.

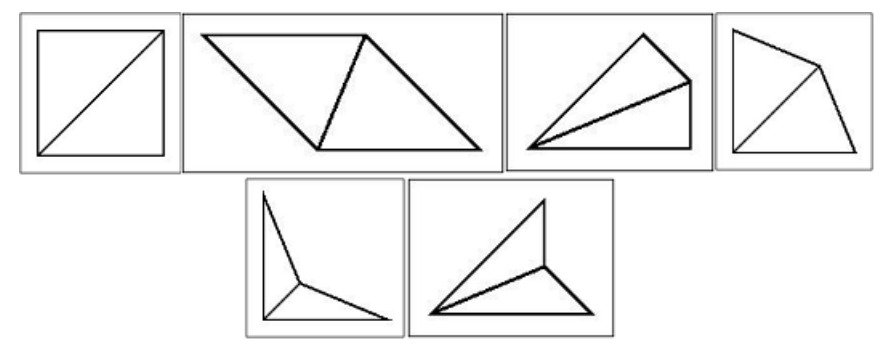

Gambar 8. Sel dan elemen perantara dalam muqarnas: bujur sangkar, jajaran genjang, belah ketupat, kendi, biped besar dan biped kecil. Sumber: www2.iwr.uniheidelberg.de/groups/ngg/Muqarnas/basic_forms.php?L=E
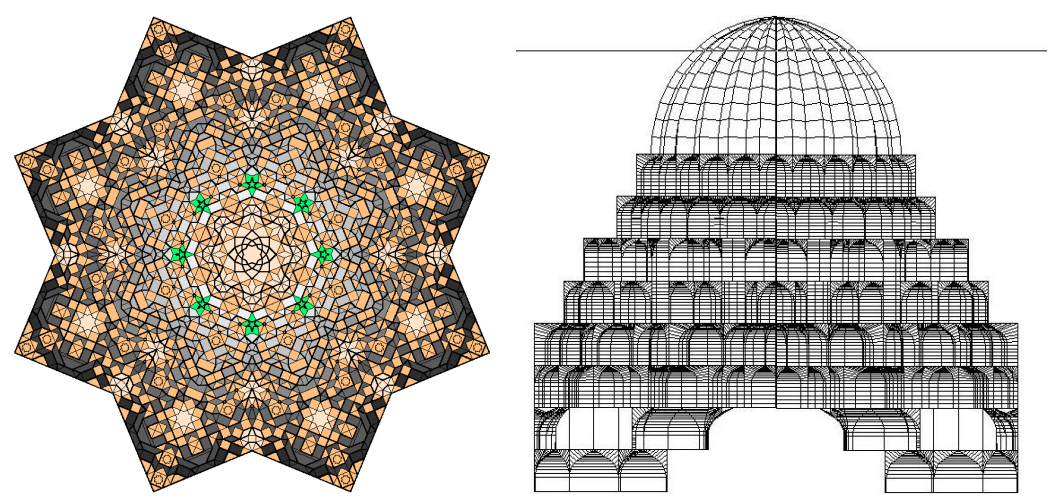

Gambar 9. Proyeksi dua dimensi muqarnas. Sumber: www.archnet.org/library 


\section{Fungsi Arsitektural Muqarnas}

Secara arsitektural, muqarnas bukanlah sekedar elemen dekoratif semata. Tekstur tiga dimensional yang dimilikinya, membuat muqarnas memantulkan dan membaurkan cahaya yang masuk dari luar, ke ruang yang berada di bawahnya (http://www.islamicart.com). Dengan demikian, ruang mendapatkan penerangan difus yang merata dan tidak menyilaukan. Cahaya dalam arsitektur, merupakan salah satu elemen terpenting yang mempengaruhi suasana ruang. Cahaya membentuk kedalaman ruang, gelap-terang dan pembayangan yang menentukan proporsi ruang secara keseluruhan. Cahaya yang masuk melalui jendela-jendela di sekeliling kubah dan mengenai relung-relung geometris muqarnas, menghasilkan efek pembayangan yang dramatis dan menyentuh kesadaran tiga dimensional (ruang) pengamatnya.

Muqarnas dapat pula berfungsi sebagai elemen akustik bagi ruang di bawahnya. Relung-relung yang terdapat pada muqarnas berfungsi sebagai alat penyerapan dan refleksi difus suara. Muqarnas merupakan penerapan konsep 'building as a specific system for itself'. Artinya, elemen bangunan ini dirancang sebagai suatu sistem yang mengatasi sendiri masalah-masalah yang terdapat di dalamnya, seperti masalah akustik, pencahayaan, dan sebagainya (Matin, 2005: 4). Dengan demikian, tidak dibutuhkan penambahan elemen-elemen akustik khusus di dalam bangunan yang bersangkutan.
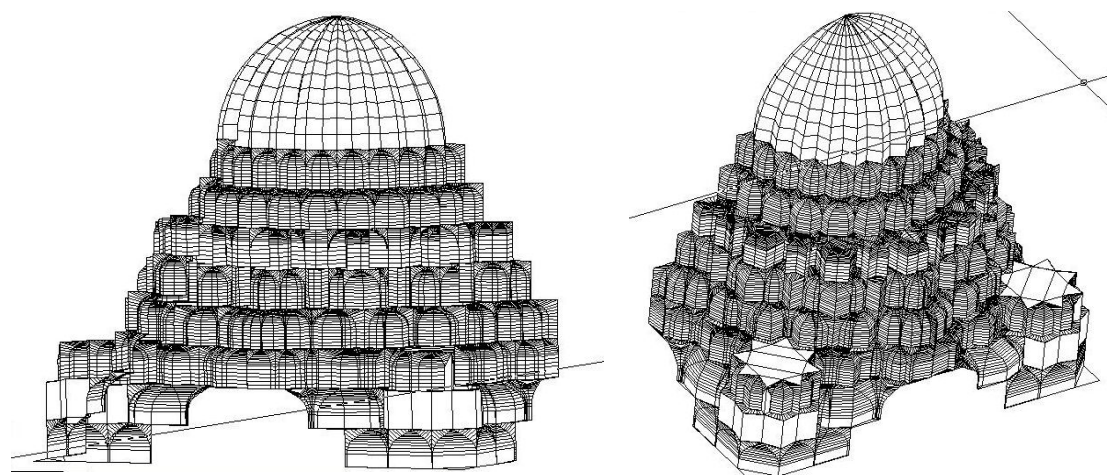

Gambar 10. Relung-relung dalam muqarnas sebagai alat refleksi difus suara. Sumber: www.archnet.org/library

\section{Pelajaran dari Lebah}

Kerumitan perhitungan matematis pada bidang lengkung yang berbentuk kubah, melukiskan betapa tingginya estetika ciptaan Allah SWT yang sering kali diremehkan oleh manusia, yaitu sarang lebah. Di dalam al Quran, Allah berfirman: 
"Dan Tuhanmu mewahyukan kepada lebah: 'Buatlah sarang-sarang di bukit-bukit, di pohon-pohon kayu, dan di tempat-tempat yang dibikin manusia'... Sesungguhnya pada yang demikian itu benar-benar terdapat tanda (kebesaran Tuhan) bagi orang-orang yang memikirkan" (QS an Nahl: 68-69).

Hal ini menunjukkan, bahwa kemampuan lebah membuat sarang yang teramat rumit merupakan kemampuan yang diilhamkan Allah SWT kepada mereka. Dalam bukunya Arsitek-arsitek di Alam, Harun Yahya mengemukakan bahwa kantung-kantung heksagonal pada sarang lebah merupakan bentuk yang paling optimal sebagai sarana penyimpanan madu, dibandingkan dengan bentuk-bentuk segi empat, segi tiga, segi lima, ataupun lingkaran (Yahya, 2003: 19). Bentuk-bentuk lingkaran yang disatukan menyisakan ruang-ruang kecil yang tak dapat digunakan. Sementara itu, bentuk-bentuk segi empat dan segi tiga membutuhkan bahan baku dinding yang lebih banyak daripada bentuk heksagonal, untuk ruang-ruang dengan luas yang sama.

Secara horisontal, proporsi dari setiap relung dalam muqarnas diperhitungkan dengan cermat, sehingga tidak terdapat ruang sisa dalam pertemuan bagian awal dan akhirnya. Begitu pula secara vertikal, permainan besar kecil relung menunjukkan komposisi yang sangat baik secara visual. Hal ini tentu membutuhkan kecerdasan dan kemampuan yang tinggi dalam perhitungannya. Seniman-seniman Muslim pada masa lalu membutuhkan waktu yang cukup lama untuk merancang dan mengembangkan desain muqarnas secara mendetail. Sebaliknya, lebah sebagai makhluk yang teramat kecil dan lemah dapat dengan mudah membuatnya setiap hari dengan ijin Allah SWT. Konsep kesadaran akan keterbatasan manusia di hadapan Khaliqnya inilah yang menjiwai setiap desain karya arsitektur Islam di masa lalu.

Dalam tataran makna, perulangan-perulangan desain yang mengalir seolah tanpa akhir dalam muqarnas, merupakan gambaran konseptual dari keyakinan manusia akan kekuasaan Allah SWT. Pola-pola perulangan dan kontinuitas dalam seni dekorasi Islam, sebagian besar dijiwai oleh kesadaran makhluk akan kebesaran dan kekuatan Allah SWT yang tanpa batas. Pola-pola geometris itu dikembangkan sedemikian rupa, sehingga orang yang mengamatinya tak dapat membedakan batas awal dan akhirnya (www.islamicart.com).

Dalam literatur lain, disebutkan bahwa muqarnas merupakan interpretasi dari tempat yang tinggi. Seperti sarang lebah yang selalu terletak di tempat yang tinggi, muqarnas terletak di langit-langit ruang, kepala kolom, balkon menara dan relung-relung kubah bangunan. Dari bagian bawah kubah, seseorang akan melihat jauh ke atas kepada hanya satu titik yang tertinggi. Hal 
ini merupakan interpretasi dari kesadaran manusia akan ke Maha Tinggian Allah SWT (Esposito, 1999: 52).

\section{Simpulan}

Dalam dunia arsitektur Islam, keberadaan muqarnas merupakan salah satu kekayaan dan warisan sejarah yang tidak ternilai harganya. Keindahankeindahan yang tampak dari kemunculan bentuknya, sebenarnya hanyalah manifestasi dari keindahan sesungguhnya yang terkandung di dalam nilai-nilai Islam. Bentuk dalam arsitektur Islam, bukanlah semata-mata dinikmati melalui panca indra. Bentuk itu harus mengantarkan manusia kepada kesadaran yang lebih tinggi (transendensi) akan kebesaran dan keesaan Allah SWT. Begitu pula halnya dengan muqarnas. Dengan pola-pola infinitnya, muqarnas mengantarkan manusia yang mengamatinya memahami dan menyadari akan sifat-sifat ketakterhinggaan Allah SWT yang melampaui ruang dan waktu. Pada akhirnya, seni menjadi suatu penguat dan penegak keyakinan agama (Al Faruqi, 1986: 82).

Demikianlah, bentuk-bentuk arsitektur yang hadir di masa lalu selalu terhubung dengan keimanan dan keyakinan yang mendalam akan keagungan dan kebesaran Allah SWT. Seniman-seniman dan arsitek di masa lalu tak pernah melepaskan diri dan keilmuan mereka dari Islam sebagai jalan hidup (the way of life) mereka. Karenanya, setiap karya arsitektur yang hadir selalu terasa lebih hidup dan bermakna.

\section{Daftar Pustaka}

Al-Faruqi, Ismail Raji. 1986. islamic architecture. http://www.en.wilkipedia. org/wiki/islamic_architecture

Al-Faruqi, Ismail Raji. 1986. Concept of Decoration in Islamic Architecture. http:// www.islamicart.com/main/architecture/decorate.html

Esposito, John L. 1999. The Oxford History of Islam. Oxford University Press: New York.

Hattstein, M dan Delius, P. 2000. Islam Art and Architecture. Konemann: Cologne.

Hillenbrand, Robert. 1994. Islamic Architecture: Form, Function and Meaning. Columbia University Press: New York. 
Matin, Andra. 2005. Peranan Akustik pada Perencanaan Arsitektur. Disampaikan pada Seminar Nasional 'Acoustic in Aesthetic'. Surabaya, 26 September 2005.

Yahya, Harun. 2003. Arsitek-arsitek di Alam. Penerbit Dzikra: Bandung.

www2.iwr.uni-heidelberg.de/groups/ngg/Muqarnas/intro.php?L=E

www.collection 1.libraries.psu.edu/cdm4/item viewer.php?

www.islamicart.com

www.arcnet.org/library

www.mrfs.net/trips/2003/Spain/Nasrid Palace/Nasrid Palace.html

www.muslimheritage.com/topics/default.cfm?TaxonomyTypeID=2\&Taxono mySubTypeID $=18 \&$ TaxonomyThirdLevelID $=7$ 